\section{Use of Cover Crop Mulches in a No-till Furrow- irrigated Processing Tomato Production System}

\author{
E.V. Herrero, ${ }^{1}$ J.P. Mitchell, ${ }^{1}$ \\ W.T. Lanini, ${ }^{1}$ S.R. Temple, ${ }^{2}$ \\ E.M. Miyao,${ }^{3}$ R.D. Morse,${ }^{4}$ \\ and E. Campiglia ${ }^{5}$
}

ADDITIONAL INDEX WORDS. Lycopersicum esculentum, 'Sava' snail medic, Medicago scutellata, 'Sephi' barrel medic, Medicago truncatula, triticale, $\mathrm{X}$ Triticosecale, woolypod vetch, Vicia dasycarpa, rye, Secale cereale, soil nitrogen, weed management, no-till

Summary. No-till processing tomato (Lycopersicum esculentum Mill.) production in four winter cover cropderived mulches was evaluated in 1997 and 1998 in Five Points, Calif. The effectiveness of two medics, 'Sava' snail medic (Medicago scutellata Mill.) (sava), and 'Sephi' barrel medic (Medicago truncatula Gaertn.) (sephi), and two cereal/legume cover crop mixtures, triticale/'Lana' woolypod vetch (X Triticosecale Wittm./Vicia

This paper is a portion of a thesis by E.V. Herrero in partial fulfillment of MS degree requirements at the University of California, Davis. This research was supported in part by grants from the University of California Sustainable Agriculture Research and Education Program, the California Tomato Research Institute, the USDA Smith-Lever IPM Program and the California Tomato Commission. The cost of publishing this paper was defrayed in part by the payment of page charges. Under postal regulations, this paper therefore must be hereby marked advertisement solely to indicate this fact.

${ }^{1}$ Department of Vegetable Crops and Weed Science, University of California, Davis, CA 95616 (mitchell@uckac.edu).

${ }^{2}$ Department of Agronomy and Range Science, University of California, Davis, CA 95616.

${ }^{3}$ University of California Cooperative Extension, Woodland, CA 95695

${ }^{4}$ Department of Horticulture, Virginia Polytechnic Institute and State University, Blacksburg, VA 24061.

${ }^{5}$ Dipartimento di Produzione Vegetale, Universita della Tuscia, Via S. Camillo de Lellis, Viterbo, IT. dasycarpa Ten.) (triticale/vetch) and rye/'Lana' woolypod vetch (Secale cereale L./V. dasycarpa) (rye/vetch), was compared with two conventionally tilled fallow controls (with and without herbicide) (fallow $+h$ and fallow-h) in suppressing weeds and maintaining yields with reduced fertilizer inputs. The comparison was conducted as a split plot, with three $\mathbf{N}$ fertilization rates $(0,100$, and 200 $\mathrm{lb} / \mathrm{acre} ; 0,112$, and $224 \mathrm{~kg} \cdot \mathrm{ha}^{-1}$ ) as main plots and cover crops and fallow controls as subplots. Tomato seedlings were transplanted 3 weeks after the cover crops had been mowed and sprayed with herbicide. There were no significant differences in weed cover in the no-till cover crop treatments relative to the fallow controls in 1997. Early season weed suppression in rye/vetch and triticale/vetch plots was similar to herbicide-treated fallow $($ fallow $+h)$ in 1998, however, later in the 1998 season weed suppression was best in the fallow $+h$. Tissue $\mathbf{N}$ was highest in the fallow treatments in both 1997 and 1998. Yields were highest in the triticale/vetch and fallow and lowest in sephi treatments in 1997, but there were no differences among treatments in $\mathbf{1 9 9 8}$. These results demonstrate the feasibility of no-till mulch production of furrow irrigated processing tomatoes and identify opportunities for further optimization of the system.

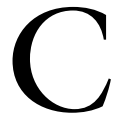
over crop mulches have potential use in both large and small-scale vegetable production in low-input no-till systems (Abdul-Baki and Teasdale, 1993) for suppressing weeds (Creamer et al., 1996; Teasdale and Abdul-Baki, 1998), providing $\mathrm{N}$ and reducing soil erosion (Coolman and Hoyt, 1993). In the eastern United States the use of organic mulches derived from winter cover crops has been proposed as a means to sustain soil quality by reducing soil erosion and increasing soil organic matter (Abdul-Baki and Teasdale, 1993). The winter annual legume hairy vetch (Vicia villosa Roth.) increased tomato yield relative to plastic mulch with no hairy vetch at lower $\mathrm{N}$ fertilizer application rates by enriching soil $\mathrm{N}$ via atmospheric fixation (Abdul-Baki et al., 1996). Hairy vetch mulch also reduces weed emergence and water loss (Abdul-Baki, and Teasdale, 1995; Abdul-Baki et al., 1995). Little effort has been made, however, to develop a suitable no-till mulch system in California's central valley $(\mathrm{CV})$ which, unlike the rainfed southeastern US, is characterized by dry summers, large-scale farms and furrow irrigation systems which are thought to make crop production in surface residues difficult. An additional problem in introducing no-till mulch systems in California has been the absence of suitable equipment. The recently developed no-till transplanter (Morse, 1998), however, offers a possible solution to this problem and may make the system potentially adaptable to large-scale farms.

Tomato production in California's $\mathrm{CV}$ is characterized by intensive tillage, high rates of applied fertilizer, and frequent irrigation (Mitchell et al., $2000)$. Weeds are usually ranked as the number one pest problem for California's CV processing tomato growers interested in reducing agrichemical inputs (Flint and Klonsky, 1985). Manual weed control costs have been estimated at about $\$ 108$ per acre (\$267 per hectare) for a processing tomato crop in Yolo County where either preplant or preemergent herbicides are used in combination with post emergence herbicide incorporation (Miyao et al., 1997). Increasing interest in more biologically based cropping alternatives and pressure to reduce the use of herbicides have led researchers to test organic mulches for their ability to reduce weeds (Creamer et al., 1996; Teasdale and Abdul-Baki, 1998).

The objectives of this research were to compare the effectiveness of no-till cover crop mulches with conventional tillage production systems for suppressing weeds and maintaining yields with reduced fertilizer inputs.

\section{Materials and methods}

Crops and cultivation. The experiment was conducted in the same field at the University of California (UC) West Side Research and Extension Center in Five Points, Calif. $\left(36^{\circ} 22^{\prime} \mathrm{N}, 120^{\circ} 7.5^{\prime} \mathrm{W}\right)$ on a Panoche clay loam soil (fine-loamy, mixed Calcareous, thermic Typic torrienthent) in 1997 and 1998. Thirty-year average rainfall for this region of the $\mathrm{CV}$ is 6 inches $(155 \mathrm{~mm})$. Monthly average maximum and minimum air temperatures for this region are provided in Table 1. Two medics, ['Sava' snail medic (sava), and 'Sephi' barrel medic 
Table 1. Precipitation, maximum and minimum temperatures in Five Points, Calif.

\begin{tabular}{|c|c|c|c|c|c|c|c|c|c|c|c|c|}
\hline Parameter & Jan. & Feb. & Mar. & Apr. & May & June & July & Aug. & Sept. & Oct. & Nov. & Dec. \\
\hline Precipitation (inches) ${ }^{\mathrm{z}}$ & 1.3 & 1.2 & 1.1 & 0.5 & 0.1 & 0.1 & 0.0 & 0.0 & 0.3 & 0.3 & 0.9 & 0.9 \\
\hline Minimum $\left({ }^{\circ} \mathrm{F}\right)$ & 36.2 & 39.4 & 41.8 & 44.7 & 50.4 & 57.3 & 62.4 & 61.6 & 57.5 & 50.1 & 41.1 & 35.7 \\
\hline \multicolumn{13}{|l|}{1997} \\
\hline Precipitation (inches) & 3.0 & 0.2 & 1.0 & 0.0 & 0.0 & 0.0 & 0.0 & 0.0 & 0.2 & 0.1 & 2.7 & 1.4 \\
\hline \multicolumn{13}{|l|}{1998} \\
\hline Precipitation (inches) & 1.5 & 4.6 & 1.9 & 1.0 & 2.2 & 0.4 & 0.0 & 0.0 & 0.4 & 0.4 & 0.9 & 0.2 \\
\hline Maximum $\left({ }^{\circ} \mathrm{F}\right)$ & 57.2 & 59.1 & 66.8 & 71.4 & 72.6 & 83.7 & 93.5 & 96.1 & 87.2 & 76.9 & 64.1 & 55.4 \\
\hline Minimum $\left({ }^{\circ} \mathrm{F}\right)$ & 41.0 & 42.6 & 43.8 & 44.5 & 48.8 & 56.4 & 62.3 & 61.9 & 58.4 & 45.8 & 41.2 & 28.6 \\
\hline
\end{tabular}

${ }^{\mathrm{z}} 1.0$ inch $=25.4 \mathrm{~mm}$.

${ }^{\text {yo }} \mathrm{C}=5 / 9\left({ }^{\circ} \mathrm{F}-32\right)$.

(sephi)] and two grass/legume mixtures [triticale/'Lana' woolypod vetch (triticale/vetch) and rye/'Lana' woolypod vetch (rye/vetch)] were used as cover crop mulches in a no-till system and were compared with two conventionally tilled winter fallow treatments [with preplant herbicide (fallow $+\mathrm{h}$ ) and with no herbicide (fallow-h)] at three different $\mathrm{N}$ fertilization rates $(\mathrm{N} 0=0, \mathrm{~N} 1=100$, and $\mathrm{N} 2$ $=200 \mathrm{lb} /$ acre $)$. A split-plot design was used with $\mathrm{N}$ rates assigned to the main plots and tillage/mulch treatments to the subplots. Each subplot, replicated four times, was $15 \mathrm{ft}(4.5 \mathrm{~m})$ wide and $90 \mathrm{ft}(27.5 \mathrm{~m})$ long. Nitrogen fertilization treatments were applied in Mar. 1997 and May 1998. The same treatments were in the same plots in both years of the study. In Oct. 1996 and 1997 cover crops were sown on the top of 60 -inch $(1.5-\mathrm{m})$ center to center beds using a Schmeiser vineyard drill (Schmeiser Manufacturing, Fresno, Calif.) at the following seed rates: $20 \mathrm{lb} /$ acre $\left(22.4 \mathrm{~kg} \cdot \mathrm{ha}^{-1}\right)$ for 'Sava' snail medic and 'Sephi' barrel

Fig. 1. Effect of mulch treatment on estimated weed cover in 1998. Estimation were made after cultivation of fallow plots using a 19.4- $\mathrm{ft}^{2}$ $\left(1.8-\mathrm{m}^{2}\right)$ quadrat. Bars with the same letter within the same month are not significantly different according to the LSD test at 0.05 level. Fallow+h = fallow with herbicide; Fallow-h = fallow without herbicide; Sava = 'Sava' snail medic; Sephi = 'Sephi' barrel medic; triticale/vetch = triticale/'Lana' woolypod vetch; rye/ vetch = rye/'Lana' woolypod vetch; $\mathrm{N} 0, \mathrm{~N} 1$, and $\mathrm{N} 2=0,100$, and $200 \mathrm{lb} /$ acre $\left(0,112\right.$, and $\left.224 \mathrm{~kg} \cdot \mathrm{ha}^{-1}\right)$ of $\mathrm{N}$. medic; $27 / 62 \mathrm{lb} /$ acre $\left(30 / 70 \mathrm{~kg} \cdot \mathrm{ha}^{-1}\right)$ for triticale/'Lana' woolypod vetch and rye/'Lana' woolypod vetch mixtures. Aboveground cover crop and weed biomass were determined in 1998 from a $10.8-\mathrm{ft}^{2}\left(1-\mathrm{m}^{2}\right)$ sample in each plot by cutting plants at the soil surface before cover crop killing, drying the

a) May

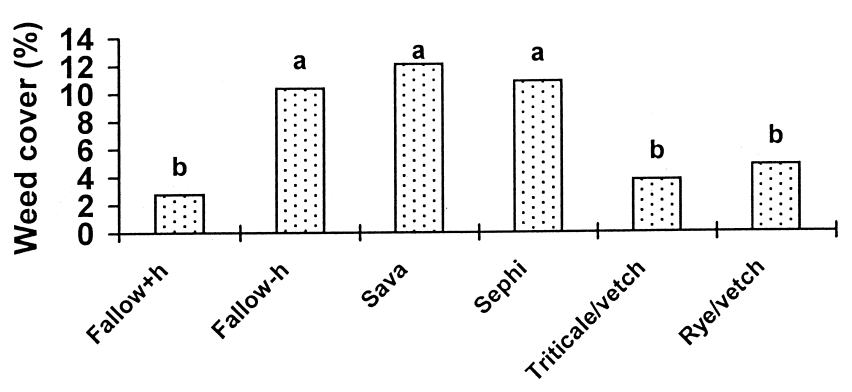

b) June

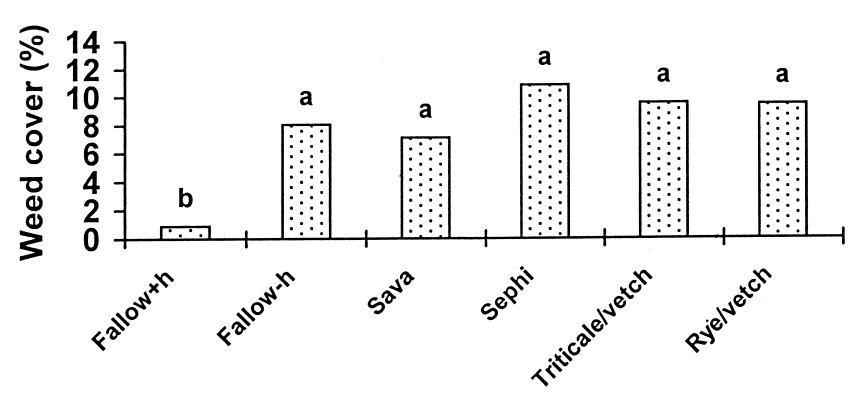

c) July

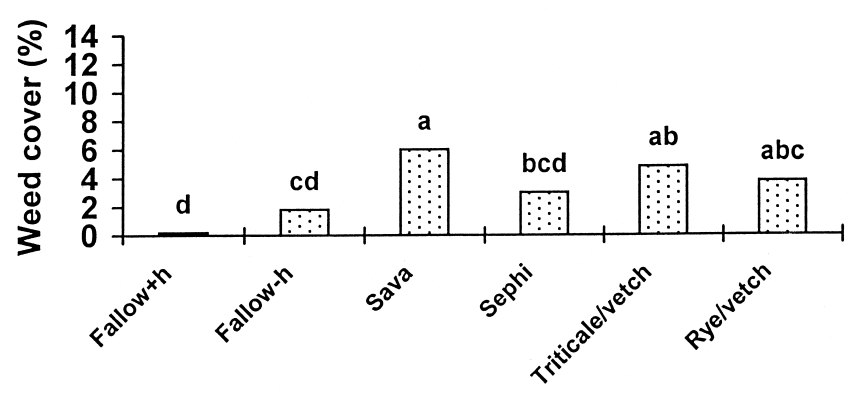


Table 2. Tomato petiole nitrate $N$ concentration $(\mathrm{ppm})$ as affected by cover crop $\mathrm{p}^{\mathrm{z}}(\mathrm{CC})$ and $\mathrm{N}$ rates.

\begin{tabular}{|c|c|c|c|c|c|c|c|c|c|c|c|c|}
\hline \multirow[b]{2}{*}{ Parameter } & \multicolumn{6}{|c|}{1997} & \multicolumn{6}{|c|}{1998} \\
\hline & 30 May & 10 June & 18 June & 26 June & 13 July & 19 July & 19 June & 29 June & 9 July & 20 July & 27 July & 3 Aug. \\
\hline Fallow+h & $6135^{y}$ & 6132 & 6333 & 2306 & 1083 & 815 & 5861 & 6024 & 5443 & 4713 & 4298 & 4440 \\
\hline Fallow-h & 5487 & 5578 & 6480 & 1594 & 918 & 1435 & 5556 & 6111 & 5951 & 4182 & 3905 & 3577 \\
\hline Sava & 3988 & 4181 & 4078 & 910 & 660 & 294 & 4438 & 3660 & 2989 & 2367 & 1528 & 1612 \\
\hline Rye & 4033 & 3169 & 2762 & 602 & 183 & 140 & 5001 & 4675 & 3720 & 2419 & 1778 & 1586 \\
\hline $\operatorname{LSD}^{\mathrm{x}}$ & 854 & 1348 & 1049 & 915 & 345 & 705 & 812 & 723 & 933 & 906 & 583 & 753 \\
\hline \multicolumn{13}{|l|}{$\mathrm{N}$ rate $^{\mathrm{w}}$} \\
\hline No & 2095 & 1045 & 2020 & 406 & 265 & 507 & 3949 & 3613 & 3229 & 1906 & 1464 & 1134 \\
\hline $\mathrm{Nl}$ & 5470 & 3991 & 3526 & 495 & 418 & 382 & 5853 & 5345 & 4389 & 3150 & 2415 & 2351 \\
\hline
\end{tabular}

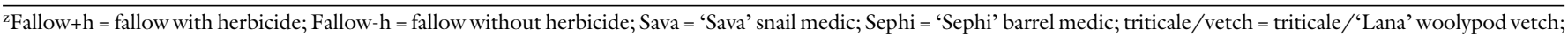
rye/vetch $=$ rye /'Lana' woolypod vetch.

${ }^{\mathrm{l}} \mathrm{ppm}=1 \mathrm{mg} \cdot \mathrm{kg}^{-1}$

$\mathrm{x}_{\mathrm{LSD}}=$ least significant difference mean separation test at 0.05 level.

${ }^{w} \mathrm{~N} 0, \mathrm{Nl}$, and $\mathrm{N} 2=0,100$, and $200 \mathrm{lb} /$ acre $\left(0,112\right.$, and $\left.224 \mathrm{~kg} \cdot \mathrm{ha}^{-1}\right)$ of $\mathrm{N}$.

vInteraction of cover crop treatment $\times \mathrm{N}$ rates.

Ns, ${ }^{\star \star *}$ Nonsignificant or significant at $P \leq 0.05$ or 0.01 , respectively.vetch.

residue at $140{ }^{\circ} \mathrm{F}\left(60^{\circ} \mathrm{C}\right)$ for $5 \mathrm{~d}$, and weighing. Medics were sprayed with a $2 \%$ solution of glyphosate and then rolled using an Unverferth rolling harrow (Unverferth Manufacturing,
Kalida, Ohio) in Mar. 1997 and 1998. Cover crop mixtures were sickle mowed at a l-inch $(2.5-\mathrm{cm})$ height in 1997 . In 1998, the triticale/vetch mix was flail mowed at 1 -inch height and the rye/ vetch mix was sprayed with a $2 \%$ solution of glyphosate and rolled. Cover crops were left lying on the beds as a mulch. Tomato ('Halley 3155 ') seedlings were transplanted on 2 Apr. 1997

Table 3. Soil nitrate $\mathbf{N}$ concentration (ppm) as affected by cover crop ${ }^{\mathrm{z}}(\mathrm{CC})$ and $\mathrm{N}$ rates.

\begin{tabular}{|c|c|c|c|c|c|c|c|c|}
\hline \multirow[b]{2}{*}{ Parameter } & \multicolumn{8}{|c|}{ Depth (inches) } \\
\hline & $0-6$ & $6-12$ & $0-6$ & $6-12$ & $0-6$ & $6-12$ & $0-6$ & $6-12$ \\
\hline \multicolumn{9}{|l|}{$\mathrm{CC}$} \\
\hline Sava & 1.19 & 3.77 & 2.28 & 1.25 & 25.20 & 15.98 & 30.40 & 21.15 \\
\hline Sephi & 1.30 & 1.58 & 1.99 & 1.39 & 22.70 & 21.32 & 40.96 & 29.03 \\
\hline Triticale & 1.16 & 0.90 & 4.07 & 2.17 & 33.27 & 24.56 & 25.86 & 24.96 \\
\hline Rye & 1.65 & 3.38 & 3.34 & 1.65 & 20.97 & 20.54 & 28.80 & 26.89 \\
\hline $\mathrm{LSD}^{\mathrm{w}}$ & NS & 2.84 & 1.21 & 1.11 & 10.64 & 8.25 & 17.03 & 11.10 \\
\hline \multicolumn{9}{|l|}{$\mathrm{N}$ rate $^{\mathrm{v}}$} \\
\hline LSD & NS & NS & NS & NS & 10.71 & 6.15 & 14.64 & 6.49 \\
\hline \multicolumn{9}{|l|}{ Interaction $^{\mathrm{u}}$} \\
\hline $\mathrm{CC} \times \mathrm{N}$ & NS & NS & NS & NS & $* * *$ & ** & NS & NS \\
\hline
\end{tabular}


a) 1997

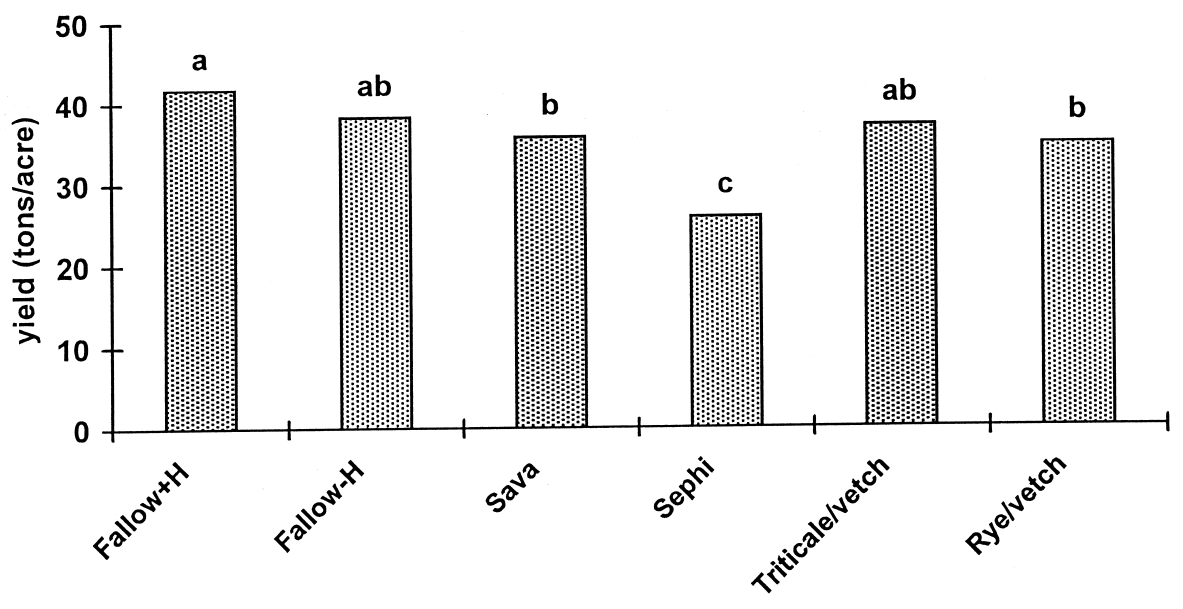

b) 1998

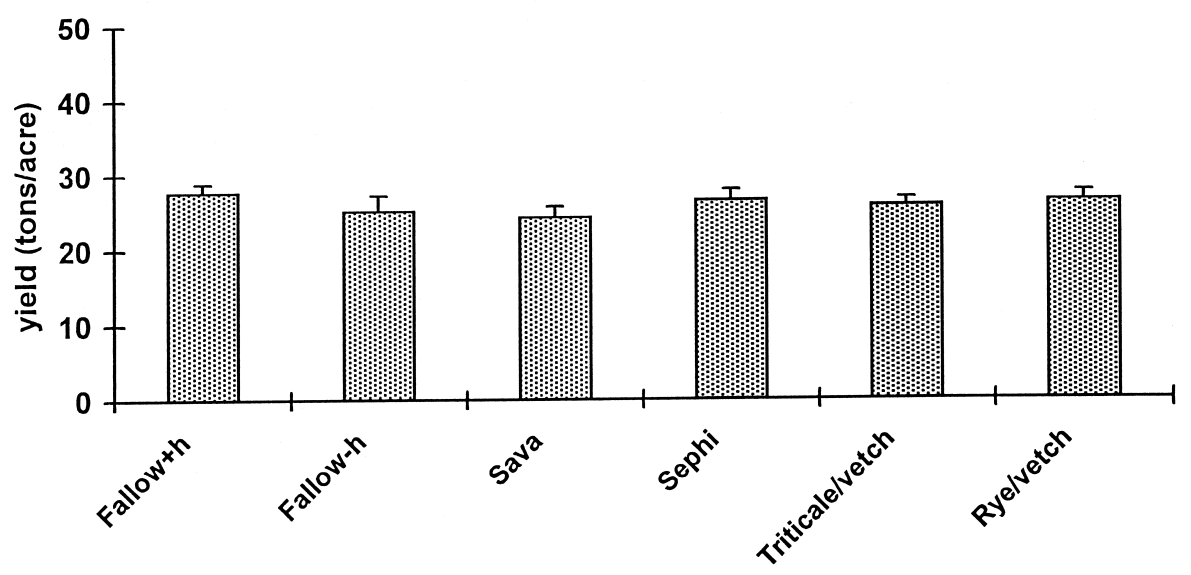

Fig. 2. Effect of mulch treatment on tomato yields. Bars with the same letter in 1997 are not significantly different according to the LSD test at 0.05 level. Vertical lines in 1998 represent sE. Fallow+h = fallow with herbicide; Fallow-h = fallow without herbicide; Sava $=$ 'Sava' snail medic; Sephi $=$ 'Sephi' barrel medic; triticale/vetch = triticale/'Lana' woolypod vetch; rye/vetch = rye/'Lana' woolypod vetch; N0, N1, and N2 = 0, 100, and $200 \mathrm{lb} /$ acre $(0,112$, and 224 $\mathrm{kg} \cdot \mathrm{ha} \mathrm{a}^{-1}$ ) of $\mathrm{N}$; 1 ton/acre $=2.24 \mathrm{t} \cdot \mathrm{ha}^{-1}$.

and 9 Apr. 1998. A Sub Surface Tillage Transplanter (B\&B No-Till, Laurel Fork, Va.) developed by Morse (1993) was used to transplant in a single row at 9 -inch $(0.22-\mathrm{m})$ distance between plants. Metham sodium was band applied as an herbicide (Lanini et al., 1998) in the fallow+h treatment at $102 \mathrm{lb} /$ acre $\left(114 \mathrm{~kg} \cdot \mathrm{ha}^{-1}\right)$ in Feb. 1997 and Mar. 1998. Hand weeding was done in all the treatments in May, June and July. In addition, cultivation was done on both fallow treatments in May and June using a Lilliston implement (Bush Hog, Selma, Ala.) before hand weeding. During the 6 weeks after transplanting, tomato plants were irrigated with a sprinkler that applied 2 inches $(50 \mathrm{~mm})$ of water weekly. Thereafter, the crop was furrow irrigated weekly with 2 inches of water until 3 weeks before harvesting. Fruit were machine harvested from $450 \mathrm{ft}^{2}(41.25$ $\mathrm{m}^{2}$ ) on 4 Aug. 1997 and from $900 \mathrm{ft}^{2}$ $\left(82.5 \mathrm{~m}^{2}\right)$ on 1 Sept. 1998 , and weights of red, green and culls recorded.

WeEd cover. Weed cover was estimated before fallow plot cultivation in May, June and July in 1998 and in July 1997, and after cultivation in May and June 1997. Three 19.4- $\mathrm{ft}^{2}(1.8-$ $\mathrm{m}^{2}$ ) quadrats were randomly placed on the center bed of each plot parallel to the plant row and percent weed cover was visually estimated.

Tomato leaf $\mathrm{N}$ content. Twenty of the youngest fully expanded leaves were sampled from each subplot about every $8 \mathrm{~d}$, six times starting 30 May and 19 June 1997 and 1998, respectively. Sampling corresponded to the period when tomatoes were in the ten true leaf stage up to fruit ripening. The samples were dried $24 \mathrm{~h}$ at $140{ }^{\circ} \mathrm{F}$, ground and analyzed separately for total $\mathrm{N}$ in the leaflets based on the method of Dumas (1831) later modified by Sweeny (1989) and petiole nitrate $\mathrm{N}\left(\mathrm{NO}_{3}-\mathrm{N}\right)$ using the procedure of Carlson et al. (1990) at the UC Division of Agriculture and Natural Resources (DANR) Analytical Lab at Davis using a N gas analyzer (FP 428; LECO Corp., St. Joseph, Mich.).

SOIL NITROGEN. Soil cores 1 inch in diameter $(2.5-\mathrm{cm})$ were taken four times in 1998, and subdivided into 0 to 6 and 6 to 12 inch depth $(0$ to 15 and 15 to $30 \mathrm{~cm}$ ) increments for $\mathrm{N}$ content determinations so as to relate differences in tissue $\mathrm{N}$ levels seen in 1997 to soil N pools. Three sub samples were taken from each plot, mixed, and kept at $39.2^{\circ} \mathrm{F}\left(4^{\circ} \mathrm{C}\right)$ before extracting with $\mathrm{KCl}$. About $0.22 \mathrm{lb}(100 \mathrm{~g})$ of each sample was subsampled in the lab for gravimetric water content. The remainder of each sample and the $\mathrm{KCl}$ extracts were sent to the UC Davis DANR lab for total N, KCl extractable $\mathrm{NO}_{3}-\mathrm{N}$ and $\mathrm{NH}_{4}-\mathrm{N}$ determinations as described by Carlson et al. (1990).

\section{Results}

COVER CROP BIOMASS. In 1998 more biomass was produced by the cereal/legume cover crop mixtures relative to the medics $[0.126,0.103$, 0.039 , and $0.017 \mathrm{lb} / \mathrm{ft}^{2}(0.618,0.503$, 0.193 , and $0.084 \mathrm{~kg} \cdot \mathrm{m}^{-2}$ ) of dry matter for triticale/vetch, rye/vetch, sephi and sava, respectively]. A similar pattern of biomass production among treatments and generally more biomass in all treatments was observed in 1997 (data not shown).

WeEd COVER. In 1997, weed cover varied between 1 and $4 \%$ and did not differ among treatments (data not shown). In Spring 1998, because of higher precipitation (Table 1), weed populations were higher than in 1997. Weed cover in May under rye/vetch and triticale/vetch mulches was similar to under herbicide-treated plots (Fig 1A). The medic cover crop mulches exerted very little weed suppression and weed cover was similar to or higher than under the fallow with 
Table 4. Yield and fruit quality as affected by $\mathbf{N}$ rates.

\begin{tabular}{|c|c|c|c|c|c|}
\hline Year & $\mathbf{N}$ rates $^{\mathrm{z}}$ & Yieldy (tons/acre) & $\operatorname{Red}(\%)$ & Green (\%) & Rot (\%) \\
\hline \multicolumn{6}{|l|}{1997} \\
\hline & No & $30.83 b^{x}$ & $87.38 \mathrm{ab}$ & $5.3 \mathrm{~B}$ & $7.32^{\mathrm{NS}}$ \\
\hline & $\mathrm{N} 2$ & $38.78 \mathrm{a}$ & $85.3 \mathrm{~b}$ & $9.79 \mathrm{a}$ & $4.9^{\mathrm{NS}}$ \\
\hline \multicolumn{6}{|l|}{ Interaction $^{\mathrm{w}}$} \\
\hline $\mathrm{CC} \times \mathrm{N}$ & & NS & NS & NS & NS \\
\hline & $\mathrm{Nl}$ & $26.45^{\mathrm{Ns}}$ & $83.3 \mathrm{ab}$ & $13.48 \mathrm{~B}$ & $3.22^{\mathrm{NS}}$ \\
\hline & $\mathrm{N} 2$ & $25.86^{\mathrm{NS}}$ & $80.18 \mathrm{~b}$ & $16.19 \mathrm{a}$ & $3.63^{\mathrm{NS}}$ \\
\hline \multicolumn{6}{|l|}{ Interaction } \\
\hline $\mathrm{CC} \times \mathrm{N}$ & & NS & NS & NS & ** \\
\hline
\end{tabular}

${ }^{\mathrm{z}} \mathrm{N} 0, \mathrm{Nl}$, and $\mathrm{N} 2=0,100$, and $200 \mathrm{lb} /$ acre $\left(0,112\right.$, and $\left.224 \mathrm{~kg} \cdot \mathrm{ha}^{-1}\right)$ of $\mathrm{N}$.

y Includes red fruit only; 1 ton $/$ acre $=2.24 \mathrm{t} \cdot \mathrm{ha}^{-1}$.

xValues followed by the same letter within columns and year are not significant according to the least significant difference test at 0.05 level.

winteraction $\mathrm{N}$ rates $\times$ cover crop treatments.

Ns, ${ }^{\star *}$ Nonsignificant or significant at $P \leq 0.01$ respectively.

no herbicide. As cover crop residue decomposed, rye/vetch and triticale/ vetch were progressively less effective at suppressing weeds (Fig $\mathrm{IB}$ and C).

TISSUE AND SOIL NITROGEN. Tissue $\mathrm{N}$ content, either unassimilated $\mathrm{NO}_{3}$ $\mathrm{N}$ in petioles (Table 2) or total $\mathrm{N}$ in the whole leaf (data not shown) was highest in $\mathrm{N}$ fertilized plots and, in most cases, higher under fallow than under cover crop treatments. Differences between fallow and cover crop treatments increased from June to August in both years (Table 2), when soil $\mathrm{NO}_{3}-\mathrm{N}$ was higher under cover crop treatments than under the fallow treatments (Table 3 ).

Soil $\mathrm{NO}_{3}-\mathrm{N}$ concentration was higher before, but lower after fertilization, under fallow relative to cover crop treatments (Table 3 ). Soil $\mathrm{NH}_{4}-$ $\mathrm{N}$ represented a small proportion of the total inorganic $\mathrm{N}$ and was not affected by fertilization rates (data not shown). Ammonium $\mathrm{N}$ was increased by cover crops only for the upper layer on the sampling date $7 \mathrm{~d}$ after mowing the cover crop (DAMCC). The $\mathrm{NH}_{4}^{-}$ $\mathrm{N}$ values at 7 DAMCC for fallow+h, fallow-h, sava, sephi, triticale/vetch and rye/vetch treatments were 0.40 , $0.67,1.28,1.90,2.59$, and $3.17 \mathrm{ppm}$ $\left(\mathrm{mg} \cdot \mathrm{kg}^{-1}\right)$, respectively $(\mathrm{LSD}=1.77$ at 0.05 level).

TOMATO YIELD AND FRUIT QUALITY. In 1997, tomato yields under triticale/vetch mulch were similar to those under either fallow (Fig. 2A). Yield was significantly lower with the sephi mulch than with the other mulches in 1997. Mulch treatments did not affect tomato yield in 1998 (Fig. 2B). In
1998, planting was delayed about 1 month due to wet spring weather. The average tomato yield was significantly lower in 1998 than in 1997. Fertilization rates increased yields in 1997 (Table 4) but not in 1998. The chopped cover crop residues used in this study did not adversely impact mechanical harvester efficiency. However, if residues are not adequately chopped, difficulties in mechanical harvesting may occur.

Soluble solids was not affected either by fertilization or cover crop treatments (data not shown). The percentage of green fruit was increased under higher fertilization rates in both years (Table 4 ).

\section{Discussion}

Unlike other reported results for processing tomatoes (Abdul-Baki et al., 1996), fresh market tomatoes (Abdul-Baki and Teasdale, 1993) or other vegetables (Morse, 1993; Skarphol et al., 1987; Abdul-Baki and Teasdale, 1997), the use of no-till organic mulches in this experiment did not increase crop yields compared to conventional practices (Fig 2 and Table 6). This study demonstrated, however, the feasibility of planting, irrigating, harvesting and maintaining productivity in certain mulches in California's CV where no-till tomato production practices are currently not used.

Weed suppression is one of the possible benefits of using organic mulches (Creamer et al., 1996). In our experiment cover crops were as effective as herbicides at suppressing weeds in 1997 because of low weed population in that year. Higher aboveground biomass and less rainfall in 1997 than in 1998 led to slower decomposition and perhaps better weed control. This confirms other findings (Teasdale and Abdul-Baki, 1998) that high cover crop biomass may be an effective alternative to herbicide use at least under low weed pressure conditions. Legumes, when grown alone, tend to produce less aboveground biomass and, because of lower $\mathrm{C}$ to $\mathrm{N}$ ratios, are prone to faster decomposition rates than grass-legume mixtures. Thus, better weed suppression is often seen in grass-legume mixtures than pure legumes (Teasdale and Abdul-Baki, 1998). In contrast, under conditions of high rainfall and/or less initial cover crop aboveground biomass in 1998 , herbicide application combined with cultivation resulted in more adequate weed control and kept weed populations suppressed. Cultivation with no herbicide (fallow-h) tended to be more effective than cover crops after the second cultivation (Fig. 1). This is probably because of a depletion of the seed bank by repeated killing of seedlings by cultivation as they germinated in the season or perhaps cultivation left a loose and dry surface layer of soil in which weed seedlings could not establish.

Most criteria for cover crop selections come from the eastern U.S. where climatic conditions are dramatically different from California. In the eastern U.S., wetter and colder winters have been the main factors considered in the selection of cover crops species. 
Consequently, efficiency in $\mathrm{N}$ fixation and cold hardiness have been traits sought in those species (USDA, 1994). In fact, $\mathrm{N}$ use efficiency has been enhanced by the use of hairy vetch in notill mulched tomatoes in Maryland (Abdul-Baki et al., 1997). However, this benefit was not seen in our study because we found no fertilization by cover crop treatment interaction for yield. Although soil inorganic $\mathrm{N}$ tended to be higher under mulches, especially after fertilization, tissue $\mathrm{N}$ concentration was consistently lower in both years, suggesting that $\mathrm{N}$ availability did not match crop uptake (Tables 2 and 3 ) or that $\mathrm{N}$ uptake under cover crop treatments was slower than under conventional fallow plots perhaps due to less root growth in no-till plots. In a number of studies, soil bulk density increased in no-till treatments (Triplett et al., 1968; Griffith et al., 1977; Stirzaker et al., 1992). Soil density often determines the potential for roots to grow and the ability of the plants to explore more soil and consequently absorb more nutrients. On the other hand, reduction of leaf area index with the consequent decrease in photosynthetically active radiation (PAR) interception has been reported as the main effect of $\mathrm{N}$ deficiency on yields in organic systems where legume cover crops and manure are the only source of $\mathrm{N}$ (Cavero et al., 1997). In 1997 lower yields under sephi and sava were probably related to a reduced leaf area and to less PAR interception under these treatments which also had lower tissue $\mathrm{N}$ content than fallow $+\mathrm{h}$ (Table 2).

Based on these results, the development of no-till cover crop mulch systems appears feasible for sustaining productivity of furrow-irrigated tomatoes in California. In this study, no-till systems using grass/legume mixtures as mulches provided early season weed suppression. Additional research is needed to develop supplementary weed management strategies and to optimize the $\mathrm{N}$ provision potential for these systems.

\section{Literature cited}

Abdul-Baki, A.A. and J.R. Teasdale. 1993. A no-tillage tomato production system using hairy vetch and subterranean clover mulches. HortScience 28:106-108.

Abdul-Baki, A.A. and J.R. Teasdale. 1995. Establishment and yield of sweet corn and snap beans in a hairy vetch mulch. Proc. 4th Natl. Symp. Stand Establishment of Horticultural Crops. Monterey, Calif. 2326 Apr.

Abdul-Baki, A.A. and J.R. Teasdale. 1997. Snap bean production in conventional tillage and in no-till hairy vetch mulch. HortScience 32:1191-1193.

Abdul-Baki, A.A., J.R. Stommel, A.E. Watanda, J.R. Teasdale, and R.D. Morse. 1996. Hairy vetch mulch favorably impacts yields of processing tomatoes. HortScience 31:338-340.

Abdul-Baki, A.A., J.R. Stommel, and J.R. Teasdale. 1995. Vetch mulch fetches more veggies. Agr. Res.43(5):10-11.

Abdul-Baki, A.A., J.R. Teasdale, and R.F. Korack. 1997. Nitrogen requirement of fresh-market tomatoes on hairy vetch and black polyethylene mulch. HortScience 32:217-221.

Carlson, R.M., R.I. Cabrera, J.L. Paul, J. Quick, and R.Y. Evans. 1990. Rapid direct determination of ammonium and nitrate in soil and plant tissue extracts. Commun. Soil Sci. Plant Anal. 21:1519-1529.

Cavero, J., R.E. Plant, C. Shennan, and D.B. Friedman. 1997. The effect of nitrogen source and crop rotation on the growth and yield of processing tomatoes. Nutrient Cycling in Agroecosystems 47:271-282.

Coolman, R.M. and G.D. Hoyt. 1993. The effects of reduced tillage on the soil environment. HortTechnology 3:143145 .

Creamer, N.G., M.A. Bennett, B.R. Stinner, and J. Cardina. 1996. A comparison of four processing tomato production systems differing in cover crop and chemical inputs. J. Amer.Soc. Hort. Sci. 121:559568 .

Dumas, J.B. 1831. Sur les procédés de l'analyse organique. De Chimie., XLVII. P.195-213.

Flint, M.L. and K. Klonsky 1985. Pest management practices in processing tomatoes. Calif. Agr. 39(1/2):19-20.
Griffith, D.R., J.V. Mannering, and W.C. Moldenhauer. 1977. Conservation tillage in the Eastern Corn Belt. J. Soil Water Cons. 32:20-28.

Lanini, W.T., G. Miyao, B. Fisher, J. Orr, H. Agamalian, and B. Mullen. 1998. UCIPM Pest management guidelines: Tomato. Univ. of Calif. DANR. Publ. 3274.

Mitchell, J.P., W.T. Lanini, S.R. Temple, P.N. Brostrom, E.V. Herrero, E.M. Miyao, T.S. Prather and K.J. Hembree. 2000. Reduced-disturbance agroecosystems in California. Proc. Intl. Congr. Ecosystem Health. August 1999. Sacramento, Calif. (in press).

Miyao, E, K. Klonsky, and P. Livingston. 1997. Sample cost to produce processing tomatoes in Yolo county. Univ. Calif. Coop. Ext.

Morse, R.D. 1993. Components of sustainable production systems for vegetables conserving soil moisture. HortTechnology 4:129-135.

Morse, R.D. 1998. Affordable small-scale equipment for production of transplanted vegetables in high residue, no-till farming systems, p. 35-40. Proceedings Emerging Soil Management Options for California. Five Points and Davis, Calif. 22-23 Apr.

Skarphol, B.J., K.A. Corey, and J.J. Meisinger. 1987. Response of snap beans to tillage and cover crop combinations. J. Soc. Amer. Hort. Sci.1 12:936-941.

Stirzaker, R. J., B. G. Sutton, and N. Collis-George. 1992. Soil management for irrigated vegetable production. I. The growth of processing tomatoes following soil preparation by cultivation, zero tillage and in situ-grown mulch. Austral. J. Agr. Res. 44:817-829.

Sweeney, R.A. 1989. Generic combustion method for determination of crude protein in feeds: Collaborative study. J. Assn. Off. Anal. Chem. 72:770-774.

Teasdale, J.R. and A.A. Abdul-Baki. 1998. Comparison of mixtures vs. monocultures of cover crops for fresh market tomato production with and without herbicides. HortScience 33:1163-1166.

Triplett, G.B., D.M. Van Doren, and B.L. Schmidt. 1968. Effect of corn stover mulch on no tillage corn yield and water infiltration. Agron. J. 60:469-472.

USDA. 1994. Sustainable production of fresh-market tomatoes with organic mulches. Farmers' Bul. FB-2279. June. 